Arq. Bras. Med. Vet. Zootec., v.71, n.2, p.711-714, 2019

\title{
Communication
}

[Comunicação]

\section{Molecular detection of bovine immunodeficiency virus (BIV) in bovines from the state of Minas Gerais, Brazil}

\author{
[Detecção molecular do vírus da imunodeficiência bovina (BIV) em bovinos do estado \\ de Minas Gerais, Brasil] \\ A.P.S. Rodrigues ${ }^{1}$, A.A. Fonseca Júnior ${ }^{2}$, G.K. Lima ${ }^{1}$, J.M. Bicalho ${ }^{1}$, \\ R.C. Leite ${ }^{1}$, J.K.P. Reis ${ }^{1 *}$ \\ ${ }^{1}$ Universidade Federal de Minas Gerais - Belo Horizonte, MG \\ ${ }^{2}$ Laboratório Federal de Defesa Agropecuária - Pedro Leopoldo, MG
}

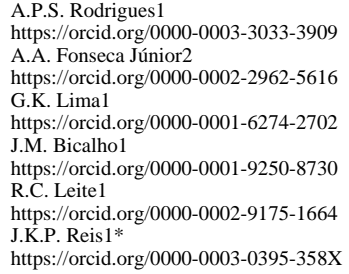

https://orcid.org/000 G.K. Lima1 J.M. Bicalho R.C. Leite1 https://orcid.org/0000-0002-9175-1664
J.K.P. Reis1* https://orcid.org/0000-0003-0395-358X
Bovine immunodeficiency virus (BIV), also known as bovine lentivirus, is a member of the Retroviridae family, and is the etiological agent of bovine viral immunodeficiency, a disease that affects cattle of various ages (Gonda et al., 1987). BIV was first isolated in 1969 in the United States from an 8-year-old cow who had persistent lymphocytosis, lymphadenopathy, progressive weakness, emaciation, fatigue, and central nervous system injury, and was originally designated as a R-29 isolate (Van Der Maaten et al., 1972). Due to its broad similarity to Human immunodeficiency virus 1 (HIV-1), BIV has been used as an animal model for understanding the pathogenesis of HIV-1 (Gonda et al., 1987).

BIV has a wide geographical distribution, with prevalence in both dairy and beef herds and can be transmitted vertically through colostrum and in the uterus via the placenta, or horizontally by the exchange of body fluids and blood (Moody et al., 2002). The virus causes a persistent infection throughout the life of the animal and clinical signs such as lymphocytosis, lymphadenopathy, weight loss, weakness, decreased milk production and some secondary infections have already been described (Brujeni et al., 2010). However, since BIV has not been associated with any specific disease or syndrome until now, the true impact of this infection on bovine animals is unknown. The diagnosis of infection can be made through the serological detection of BIV specific antibodies or molecular detection of the

Recebido em 29 de dezembro de 2017

Aceito em 9 de outubro de 2018

*Autor para correspondência (corresponding author)

E-mail: jenner@ufmg.br viral genome through the polymerase chain reaction (PCR) (Meas et al., 1998).

In Brazil, BIV has been detected in cattle from the states of Mato Grosso do Sul and Rio Grande do Sul using PCR and through the detection of antibodies to the capsid p26 protein by Western Blot (Meas et al., 2002). BIV was also detected using semi-nested PCR in peripheral blood leukocytes of buffaloes from the Amazon region (Albernaz et al., 2015).

Due to the BIV worldwide distribution, the occurrence of the disease in neighboring countries, and the scarcity of studies in Brazil, the objective of this study was to detect BIV in cattle and to estimate the occurrence of the infection in two regions of the state of Minas Gerais.

A total of 391 blood samples were collected from October/2013 to May/2014 from dairy cattle of various races and of both sexes, aged 0 to 12 years, from four farms located in two regions Zona da Mata and Central - in the state of Minas Gerais. This research survey was conducted under an approved animal use and care committee protocol (UFMG/CEUA protocol number 356/2012).

The blood was centrifuged at $1600 \mathrm{x} \mathrm{g}$ for 10 minutes followed by collecting of buffy coat, which was removed and stored at $-20^{\circ} \mathrm{C}$ until use. The buffy coat was thawed and the total 
genomic DNA of the leukocytes was extracted using the commercial kit QIAamp® DNA Blood Mini Kit (Qiagen ${ }^{\circledR}$, Hilden, Germany) according to the manufacturer's instructions.

All the extracted samples were submitted to a PCR for the detection of the glyceraldehyde 3phosphate dehydrogenase (GAPDH) normalizing bovine gene (Pinheiro de Oliveira et al., 2013). Detection of proviral DNA present in the field samples was conducted through the SN-PCR (Albernaz et al., 2015). As a positive control for SN-PCR, plasmid BIV127, kindly provided by Dr Charles Wood (Center for Virology, University of Nebraska-Lincoln), containing part of the pol gene was used. The PCR-SN products were purified through Wizard Wizard Plus Minipreps DNA Purification System (Promega, USA) according to the manufacturer's instructions, prior to cloning into pGEM $^{\circledR}-\mathrm{T}$ and pGEM $^{\circledR}$-T Easy Vector Systems (Promega, USA). The nucleotide sequences of the cloned inserts were determined using BigDye Terminator v3.1 (Applied Biosystems, USA). The sequencing results were analyzed using SeqSape version 2.7 software (Applied Biosystems, USA) and MEGA 5.0 software.

The proviral DNA was detected in $49(12.5 \%)$ of the 391 samples tested in the SN-PCR. The samples were considered positive when they amplified the target fragment of 154bp size. The specificity of six random products of PCR-SN was confirmed by cloning in pGEM $^{\circledR}-\mathrm{T}$ and pGEM $^{\circledR}-\mathrm{T}$ Easy Vector Systems (Promega, USA) followed by nucleotide sequencing. All resulting sequences showed $99 \%$ similarity with BIV pol sequences already deposited on GenBank, referring to the American strain R-29 (Accession number L04972.1).

The percentage and total of positive animals per farm tested by SN-PCR are shown in Table 1. All farms tested had at least one positive animal for BIV. Farms II and IV presented a higher index of BIV-infected animals in relation to the total number of animals tested, $21.4 \%$ and $14.3 \%$ respectively, while farms I and III presented a lower index, showing that the presence of the infection is not limited to one region and occurs in different parts of the state.
Table 1. Percentage and total of positive animals per farm tested through SN-PCR. Farms I to IV (milk cattle) located in two regions - Zona da Mata and Central - Minas Gerais

\begin{tabular}{lccc}
\hline Farm $\mathrm{n}^{\mathbf{0}}$ & $\begin{array}{c}\mathrm{N}^{\mathbf{o}} \text { Tested } \\
\text { animals }\end{array}$ & BIV & $\begin{array}{c}\text { Total } \\
(\%)\end{array}$ \\
\hline I & 163 & 21 & $12.9 \%$ \\
II & 112 & 24 & $21.4 \%$ \\
III & 95 & 1 & $1.05 \%$ \\
IV & 21 & 3 & $14.3 \%$ \\
Total & 391 & 49 & $12.5 \%$ \\
\hline
\end{tabular}

Epidemiological studies on BIV are difficult to carry out due to the absence of a simple, fast and effective test, especially when the number of animals surveyed is high. In recent years, PCR has become a very important tool in the direct detection of pathogens including BIV, and because it is a rapid and highly sensitive method, it can detect a very small amount of DNA in a relatively short period of time (Orr et al., 2003).There are no previous studies reporting the presence of BIV in Minas Gerais, although the infection has been reported in bovines from Central West and Southern Brazil (Meas et al., 2002), besides buffaloes from the Amazon region of the country (Albernaz et al., 2015).

When analyzing the farms and the percentages of infection among them, it was observed that the farm II had a greater occurrence of the infection (21.4\%), which can be justified through livestock practices, which is carried out in a semiextensive way, promoting a greater agglomeration of the animals. The constant agglomeration observed in farm II can allow through the exchange of secretions and body fluids, a horizontal transmission mechanism, as well as other environmental factors, such as the presence of hematophagous insects, which can mechanically transmit the virus from the infected animal to the naive one (St Cyr Coats et al., 1994). Farm III presented the lowest percentage, only $1.05 \%$ of the occurrence of BIV infection. The breeding system in this farm, carried out in an extensive manner, allows the animals to be free in the natural pasture, which makes it difficult to disseminate the virus in the herd, thus justifying the low occurrence at this site.

These results, when compared to other studies done in the country, showed that the regions tested in the state of Minas Gerais presented a very similar occurrence of BIV infections found 
by serology and molecular methods in studies carried out in the states of Mato Grosso do Sul and Rio Grande of the South (Meas et al., 2002) and higher than the average found in buffalo in the state of Pará (4.4\%) (Albernaz et al., 2015). This percentage was also higher than the values observed by direct detection through PCR in India $(8.8 \%)$ and moderately similar to the serology studies conducted in Japan (11.7\%) (Meas et al., 1998; Patil et al., 2003). Countries such as the Iran have a significantly higher percentage than found in this study, with $60 \%$ detection by PCR (Brujeni et al., 2010). Brazilian cattle originate in Europe and India, and since imported cattle may already be infected with BIV, it is possible that the bovine immunodeficiency virus has been present in the Brazilian herd for a long time, but detection studies have only been performed in recent years.

Regarding the use PCR, the most commonly used gene regions for detecting BIV are env and pol (Meas et al., 1998; Orr et al., 2003), but in this work the pol region was used due to its high rate of conservation among lentiviruses (Meas et al., 1998) and because of its success in the studies with buffaloes in the Amazon region of the country using the same primers (Albernaz et al., 2015). SN-PCR was able to detect the presence of BIV in cattle and the data obtained were enough to estimate, for the first time, the occurrence of the BIV in animals of the state of Minas Gerais.

This study provides important data about the presence of BIV in the state of Minas Gerais, one of the states with the largest milk production in Brazil. Canadian dairy cows infected with BIV showed a decrease in mean milk yield, and the occurrence of the virus may also be associated with secondary bacterial infections, complications at calving and early lactation (McNab et al., 1994).

This is the first survey performed for BIV in catlle of Minas Gerais state where was detected $12.5 \%$ of positive animals. The virus may be present in other regions of Brazil, however, due to the scarcity of data, epidemiological surveys are needed to confirm the occurrence and role of BIV in cattle herds.

\section{ACKNOWLEDGMENTS}

This work was supported by INCT-Pecuária, $\mathrm{CNPq}$ and FAPEMIG. Authors thank Dr. Charles Wood from Center for Virology, University of Nebraska-Lincoln for providing the plasmid BIV127 used as a positive control for SN-PCR. RCL and JKPR are CNPq fellowship recipients.

Keywords: bovine immunodeficiency vírus, PCR, Minas Gerais, Brazil

\section{RESUMO}

O vírus da imunodeficiência bovina é o agente causador da imunodeficiência viral bovina que é conhecido por infectar bovinos em todo o mundo. Como em outras infecções por retrovírus, os hospedeiros desenvolvem uma infecção de longo prazo e a maioria dos animais infectados permanece assintomática. O objetivo deste estudo foi detectar DNA proviral BIV em amostras de sangue de bovinos e estimar a ocorrência de infecção no estado de Minas Gerais, Brasil. Amostras de sangue de 391 bovinos foram coletadas de duas regiões do estado, Zona da Mata e Central. O DNA proviral foi detectado por reação em cadeia da polimerase semi-nested (SN-PCR). Os resultados de SN-PCR indicaram uma ocorrência de BIV de $12,5 \%$ no estado. Os produtos amplificados foram confirmados como BIV por sequenciamento e a similaridade da sequência de nucleotídeos com a estirpe de referência (R-29) foi de 99\%. Este é o primeiro estudo que relata a presença do BIV em Minas Gerais, Brasil. Os resultados indicam a necessidade de realizar um estudo detalhado sobre a prevalência da infecção por BIV no Brasil.

Palavras-chave: vírus da imunodeficiência bovina, PCR, Minas Gerais, Brasil 


\section{REFERENCES}

ALBERNAZ, T.T.; LEITE, R.C.; REIS, J.K.P. et al. Molecular detection immunodeficiency virus in water buffaloes (Bubalus bubalis) from the Amazon region. Braz. Trop. Anim. Health. Prod., v.47, p.1625-1628, 2015.

BRUJENI, G.K.; POORBAZARGANI, T.T.; NADIN-DAVIS, S. et al. Bovine immunodeficiency virus and bovine leukemia virus and their mixed infection in Iranian Holstein cattle. J. Infect. Dev. Ctries., v.4, p.576$579,2010$.

GONDA, M.A.; BRAUN, M.J.; CARTER, S.G. et al. Characterization and molecular cloning of a bovine lentivirus related to human immunodeficiency virus. Nature, v.330, p.388$391,1987$.

McNAB, W.B.; JACOBS, R.M.; SMITH, H.E. A serological survey for bovine immunodeficiencylike virus in Ontario dairy cattle and association between test results, production records and management practices. Can. J. Vet. Res., v.58, p.36-41, 1994.

MEAS, S.; KABEYA, H.; YOSHIHARA, S. et al. Seroprevalence and field isolation of bovine immunodeficiency virus. J. Vet. Med. Sci., v.60, p.1195-1202, 1998.

MEAS, S.; RUAS, J.F.; USUI, T. et al. Seroprevalence and molecular evidence for the presence of bovine immunodeficiency virus in Brazilian cattle. Jpn. J. Vet. Res., v.50, p.9-16, 2002.
MOODY, C.A.; PHARR, G.T.; MURPHEY, J. et al. Confirmation of vertical transmission of bovine immunodeficiency virus in naturally infected dairy cattle using the polymerase chain reaction. J. Vet. Diagn. Invest., v.14, p.113-119, 2002.

ORR, K.A.; O’REILLY, K.L.; SCHOLL, D.T. Estimation of sensitivity and specificity of two diagnostics testes for bovine immunodeficiency virus using Bayesian techniques. Prev. Vet. Med., v.61, p.79-89, 2003.

PATIL, S.S.; PATTNAIK, B.; MISHRA, N. et al. Detection of proviral genomic sequence of bovine immunodeficiency virus in Indian cattle. Curr. Sci., v.84, p.563-566, 2003.

PINHEIRO DE OLIVEIRA, T.F.; FONSECA JR, A.A.; CAMARGOS, M.F. et al. Detection of contaminants in cell cultures, sera and trypsin. Biologicals, v.41, p.407-414, 2013.

ST CYR COATS, K.; PRUET, S.B.; NASH, J.W. et al. Bovine immunodeficiency virus: incidence of infection in Mississippi dairy cattle. Vet. Microbiol., v.42, p.181-189, 1994.

VAN DER MAATEN, M.J.; BOOTHE, A.D.; SEGER, C.L. Isolation of a virus from cattle with persistent lymphocytosis. J. Natl. Cancer Inst., v.49, p.1649-1657, 1972. 